\section{Science in Poland. ${ }^{1}$}

I I I8I the Mianowski Institution was founded at Warsaw with the object of promoting the interests of science in Poland. During many years the Institution had to struggle with the suspicious hostility of the Russian Government; notwithstanding bureaucratic cavil and quibble, the Institution edited between I 88I and I9I6 more than Iooo volumes of scientific publications (originally written in Polish or translated), assisted hundreds of Polish scientific men in their work, subsidised various laboratories and research institutes, and accomplished much other valuable scientific and national work.

In I9I 8 and I9I9, as soon as Poland was free, the influence and activity of the Institution expanded in a most satisfactory manner. In 1920 a meeting of 5.33 Polish men of science, coming from all parts of the country, was held at Warsaw, under the auspices of the Institution, with the object of considering, from various points of view, the needs and claims of science in Poland and the immediate prospects of intellectual development of the country. Volume 3 of " Nauka Polska" contains most of the addresses delivered at the Congress. It deals, of course, with many subjects treated by different writers in a variety of tone and of style; it is impossible, however, not to be struck with the glowing patriotic enthusiasm and the noble attachment to the cause of science shown in its pages.

In the inaugural address Prof. Jan Rozwadowski, professor of comparative linguistics in the Jagellonian University of Cracow, takes an uncommon and highly interesting view of "Science and Life." Prof. Rozwadowski would almost suggest that even science may countenance much that is superficial, futile, irrelevant, and sometimes even insincere. Of acute criticism scientific men are rarely tolerant; yet this address, even if it contains debatable matter, shows delightfully how little right they have to throw stones at indifferent or ignorant outsiders. The width of thought, the balance and wisdom shown in this lecture are very remarkable.

It is impossible in a short article to deal with the wide range of discussion contained in other essays; we must content ourselves with enumerating some further titles. "Independence of Science and Research," "Science and Education," "Science and Art," " Social Aspects of Science," " Science and the State," " Organisation of Scientific Research," "Polish Physiography," " Science and Economic Life," "Polish and International Science"-such are the subjects treated by various writers in an interesting or inspiring manner.

The fourth volume of "Nauka Polska" contains much that is valuable and interesting both in matter and scope. Reference may be made to a collection (pp. 8r-286) of essays discussing the prospects and possibilities of scientific research in small towns or in the country, far away from libraries, laboratories, and the inspiring influence of university surroundings. Eighteen authors present us with a survey of scientific work that can be accomplished in remote parts of a large country such as Poland. Particularly valuable is Prof. Banachiewicz's contribution on "Amateur Astronomy," an article remarkable for the ability with which a variety of sound information has been epitomised, technical language, as far as possible, being avoided. In a very interesting essay Prof. Birkenmajer gives a list of gifts and benefactions to the Jagellonian University of Cracow in the fifteenth

1 “Nauka polska, jej potrzeby, organizacja i rozwój," vol. iii. pp. viii +280 , vol. iv. pp. ix +590 . (Warsaw: The Mianowski Institution,
1920 and I923.)

$$
\text { NO. } 2807 \text {, VOL. I I } 2]
$$

and sixteenth century, beginning with the gift by Queen Jadwiga of Poland, in 1399, of her jewels and other precious objects for the re-erection and endowment of the Jagellonian University, founded by her grandfather in I364. This noble example was followed by many later benefactors. Another noteworthy feature of the volume is a short but very suggestive essay by Prof. Rozwadowski on "Science, Art, and Religious Belief." We notice also the following contributions: "National and International Science," by Prof. Gawroński ; "Longevity of Chemists" (and particularly of Polish chemists), by Prof. J. Zawidzki; "Organisation of Science in France and the United States of N. America," by Messrs. Drzewiecki and Znaniecki.

In conclusion we can only say that we have laid down these volumes with a feeling of real sympathy and warm appreciation.

\section{Formation of Organic Compounds from Inorganic by the Influence of Light.}

DR. O. BAUDISCH contributes to Science of April 20 a very interesting account of work carried out by him on the photo-chemical production of organic nitrogen compounds and the influence of iron on nitrate reduction.

The purely chemical investigations originated from bacteriological experiments in which the author found that, in the case of cholera bacilli, the reduction of nitrates stands in direct relation to the oxygen respiration of the bacteria and also to their iron content. A somewhat analogous catalytic effect was discovered in investigating the reduction of nitrites by means of glucose in carbonate solution. Although no reaction takes place, even on heating under pressure, in the absence of iron, the smallest trace of an iron salt is sufficient to bring about the reduction of a large amount of nitrite. Under these conditions nitrates remain entirely unattacked, but are instantaneously reduced to nitrites even in the cold in the presence of oxygen and ferrous salts, an observation of considerable importance in connexion with biological reduction processes.

In contact with moist air, ferrous bicarbonate rapidly absorbs oxygen, yielding a labile peroxide compound, a reaction which the author compares to the fertilisation of an ovum. This is capable of forming a co-ordinated complex with the potassium nitrate, which then splits off an oxygen atom. Reduction of the nitrite is then assumed to proceed further to the extremely reactive potassium nitrosyl, $\mathrm{K}(\mathrm{NO})$, which at the same time reacts with organic substances present, especially aldehydes, to form carbon and nitrogen containing compounds. In this reaction ferrous bicarbonate and oxygen assume the rôle of light.

Ferrous bicarbonate peroxide is also capable of giving up the loosely linked oxygen molecule to oxidisable compounds, just as hæmoglobin absorbs oxygen and gives it back again for oxidation or dehydrogenation processes. The reaction is selective and depends upon the affinity of the compound to be oxidised, to form co-ordination compounds with the iron.

A comparison is drawn between the processes outlined above and the reducing action of soil bacteria, and it is concluded that the chemical reactions are, in both cases, very similar. The bacteria which do not need light most probably use the energy of the iron peroxide in rendering nitrates available for protein formation. 